\title{
PENGARUH STATUS GIZI REMAJA TERHADAP USIA MENARCHE PADA SISWI SDN DUKUH MENANGGAL SURABAYA
}

\author{
Putri Kusnita ${ }^{1}$, Damarati ${ }^{2}$
}

1. Mahasiswi Program Studi D-III Kebidanan Universitas PGRI Adi Buana Surabaya

2. Tenaga Pengajar Program Studi D-III Kebidanan Universitas PGRI Adi Buana Surabaya

\begin{abstract}
ABSTRAK
Dampak dari anak perempuan yang gemuk, memiliki kecenderungan untuk mengalami menarche lebih awal (menarche dini). Nutrisi juga mempengaruhi kematangan seksual pada gadis yang mendapat menstruasi pertama lebih dini, mereka cenderung lebih berat dan lebih tinggi pada saat menstruasi pertama dibandingkan dengan mereka yang belum menstruasi pada usia yang sama. Tujuan penelitian ini: mengidentifikasi status gizi, mengidentifikasi usia menarche dan menganalisis pengaruh status gizi remaja terhadap usia menarche. Rancangan penelitian ini menggunakan Survey cross sectional. Populasinya semua siswi kelas 4-6 di SDN Dukuh Menanggal yang telah mengalami menarche sebanyak 39 siswi. Sampel sebanyak 36 siswi. Teknik pengambilan sampelnya Random Sampling. Hasil analisis chi-square diperoleh hasil ( 4,912 > 3,481) dengan demikian Ha diterima dan Ho ditolak sehingga dapat disimpulkan bahwa "Ada Pengaruh Status Gizi (LILA) Remaja Terhadap Usia Menarche pada Siswi SDN Dukuh Menanggal Surabaya" dapat diterima dan dibuktikan kebenarannya.Simpulannya Status Gizi (LILA) pada siswi SDN Dukuh Menanggal Surabaya terbanyak pada kategori gizi baik mencapai 63,9 \%. Usia Menarche pada siswi SDN Dukuh Menanggal Surabaya terbanyak pada kategori menarche normal mencapai 80,6 \%. Ada Pengaruh Status Gizi (LILA) Remaja Terhadap Usia Menarche pada Siswi SDN Dukuh Menanggal Surabaya.
\end{abstract}

Kata Kunci : Status Gizi, Usia Menarche

\section{PENDAHULUAN}

Pubertas pada perempuan umumnya terjadi di usia 9-12 tahun, sedangkan pubertas pada lakilaki terjadi di usia yang lebih tua yaitu 9-14 tahun. Pubertas pada perempuan dapat ditandai dengan datangnya menstruasi untuk pertama kalinya (menarche). Pubertas menggambarkan fase peralihan dari masa kanak-kanak ke masa dewasa. Pada umur 12 tahun kelenjar adrenal mulai aktif menghasilkan hormone. Peristiwa yang paling dinamik pada remaja adalah timbulnya menarche pada anak perempuan yang rata-rata terjadi pada umur antara 10-12,5 tahun (pada kultur barat). Masa ini ditentukan oleh berbagai faktor, tetapi yang terpenting adalah faktor genetik. Faktor lain yang berperan penting adalah status gizi, gadis gemuk akan mendapat menarhe lebih awal daripada yang kurus. Dampak dari anak perempuan yang gemuk, memiliki kecenderungan untuk mengalami menarche lebih awal (menarche dini). Menarche sebenarnya hanya sebuah istilah medis untuk menjelaskan peristiwa menstruasi yang pertama kali dialami oleh seorang wanita. Menarche menjadi hal yang penting bagi seorang wanita dan perlu mendapatkan perhatian khusus, karena hal ini menandai awal kedewasaan biologis seorang wanita. Penelitian pendahuluan yang dilakukan di SDN Dukuh Menanggal Surabaya bahwa dari 22 siswi yang diambil secara acak dari kelas 4 hingga kelas 5 bahwa yang pertama haid pada usia 9 tahun sebanyak 7 orang $(31,8 \%)$ kemudian yang haid pada usia 10 tahun sebanyak 11 orang $(50 \%)$ dan yang haid pada usia 11 tahun sebanyak 4 orang (18,2\%). Dari data tersebut menunjukan bahwa terdapat menarche dini yang dialami oleh siswi SDN Dukuh Menanggal Surabaya. Dari data diatas perlu dilakukan penelitian guna mengidentifikasikan Pengaruh Status Remaja Terhadap Usia Menarche pada Siswi SDN Dukuh Menanggal Surabaya. Rumusan Masalah pada penelitian ini adalah Adakah Pengaruh Status Gizi Remaja Terhadap Usia Menarche pada Siswi SDN Dukuh Menanggal Surabaya ? Tujuan Penelitian: 1) Mengidentifikasi status gizi remaja putri pada 
siswi SDN Dukuh Menanggal Surabaya, 2) Mengidentifikasi Usia Menarche pada siswi SDN Dukuh Menanggal Surabaya, 3) Menganalisis Hubungan Status Gizi Remaja Putri dengan Usia Menarche pada Siswi SDN Dukuh Menanggal Surabaya.

\section{BAHAN DAN METODE}

Desain Penelitian ini menggunakan metode analitik.yaitu menggali bagaimana dan mengapa fenomena kesehatan itu terjadi. Pendekatan penelitian yang dilakukan adalah menggunakan Survey Cross Sectional ialah suatu penelitian tentang dinamika korelasi antara faktor-faktor resiko dengan efek dan cara pendekatan, observasi atau pengumpulan data sekaligus pada suatu saat (poin time approach). Penelitian dilakukan pada bulan April 2012 sampai dengan Mei 2012. Populasi penelitian ini adalah semua siswi kelas 4-6 di SDN Dukuh Menanggal yang telah mengalami menarche sebanyak 39 siswi. Dalam penelitian ini meneliti menggunakan random sampling (acak), ditujukan pada kelas 46 (Usia 9-13 tahun) di SDN Dukuh Menanggal yang telah mengalami menarche sebanyak 36 siswi. Variabel yang digunakan adalah : Pada penelitian ini, variabel bebas adalah Status Gizi (LILA) Remaja Putri. Variabel tergantungnya dalam penelitian ini adalah Usia Menarche. Alat yang digunakan adalah kuesioner/angket dan lembar observasi.

\section{HASIL DAN PEMBAHASAN}

\section{Usia Siswi}

Tabel 1: Data Usia Siswi SDN Dukuh Menanggal Surabaya pada Bulan Juni 2012

\begin{tabular}{lll}
\hline Usia & $(\mathbf{f})$ & (\%) \\
\hline 11 tahun & 20 & 55,6 \\
12 tahun & 11 & 30,5 \\
13 tahun & 5 & 13,9 \\
\hline Total & 36 & 100 \\
\hline
\end{tabular}

Data usia siswi SDN Dukuh Menanggal yang dijadikan responden pada Bulan Juni
2012 yang terbanyak adalah berusia 11 tahun sebanyak 20 orang (55,6\%).

\section{Pola Makan Siswi}

Tabel 2 : Data Pola Makan Siswi SDN Dukuh Menanggal Surabaya pada Bulan Juni 2012

\begin{tabular}{lcc}
\hline $\begin{array}{l}\text { Pola } \\
\text { Makan }\end{array}$ & (f) & (\%) \\
\hline 2 Kali & 10 & 27,8 \\
3 Kali & 26 & 72,2 \\
\hline Total & 36 & 100 \\
\hline
\end{tabular}

Data pola makan siswi SDN Dukuh Menanggal yang dijadikan responden pada Bulan Juni 2012 yang terbanyak adalah pola makan 3 kali sehari sebanyak 26 orang (72,2\%).

\section{Usia Menarche}

Tabel 3: Data Usia Menarche Siswi SDN Dukuh Menanggal Surabaya pada Bulan Juni 2012

\begin{tabular}{|l|l|l|}
\hline $\begin{array}{l}\text { Usia } \\
\text { Menarche }\end{array}$ & (f) & (\%) \\
\hline Menarche Dini & 7 & 19,4 \\
\hline Menarche Normal & 29 & 80,6 \\
\hline Total & 36 & 100 \\
\hline
\end{tabular}

Data usia menarche pada siswi SDN Dukuh Menanggal yang dijadikan responden pada Bulan Juni 2012 yang terbanyak adalah menarche normal sebanyak 29 orang $(80,6 \%)$.

\section{Status Gizi}

Tabel 4: Data Status Gizi Siswi SDN Dukuh Menanggal Surabaya pada Bulan Juni 2012

\begin{tabular}{|l|l|l|}
\hline Status Gizi & $(\mathbf{f})$ & $(\%)$ \\
\hline Gizi Kurang & 13 & 36,1 \\
\hline Gizi Baik & 23 & 63,9 \\
\hline Total & 36 & 100 \\
\hline
\end{tabular}


Data status gizi pada siswi SDN Dukuh Menanggal yang dijadikan responden pada Bulan Juni 2012 yang terbanyak status gizinya baik sebanyak 23 orang (63,9\%).

\section{Analisis Data Pengaruh status gizi remaja terhadap usia menarche pada siswi SDN Dukuh Menanggal Surabaya}

Pengaruh Status Gizi Remaja Terhadap Usia Menarche Pada Siswi SDN Dukuh dijelaskan dalam tabel tabulasi silang berikut:

Tabel 6 : Pengaruh Status Gizi Remaja Terhadap Usia Menarche Pada Siswi SDN Dukuh pada bulan Juni 2012

\begin{tabular}{|l|l|l|l|l|l|l|}
\hline \multirow{4}{*}{$\begin{array}{l}\text { Status } \\
\text { Gizi }\end{array}$} & \multicolumn{3}{|l|}{ Usia Menarche } & \multicolumn{2}{|l|}{$\begin{array}{l}\text { Menarche } \\
\text { Dini }\end{array}$} & \multicolumn{2}{l|}{$\begin{array}{l}\text { Menarche } \\
\text { Normal }\end{array}$} & \multicolumn{2}{|c|}{$\Sigma$} \\
\cline { 2 - 7 } & $f$ & $\%$ & $f$ & $\%$ & $f$ & $\%$ \\
\hline $\begin{array}{l}\text { Gizi } \\
\text { Kurang }\end{array}$ & 0 & 0,0 & 13 & 36,1 & 13 & 36,1 \\
\hline $\begin{array}{l}\text { Gizi } \\
\text { Baik }\end{array}$ & 7 & 19,4 & 16 & 44,4 & 23 & 63,9 \\
\hline Total & 7 & 19,4 & 29 & 80,6 & 36 & 100 \\
\hline
\end{tabular}

Hasil tabulasi silang antara status gizi dengan usia menarche pada siswi SDN Dukuh Menanggal bahwa yang mengalami gizi kurang semuanya pada usia menarche normal sebesar 13 orang $(36,1 \%)$ dan siswi yang mengalami gizi baik yang mengalami menarche dini sebanyak 7 orang $(19,4 \%)$ dan menarche normal sebanyak 16 orang $(44,4 \%)$. Dari hasil analisis dengan menggunakan Chi-square diperoleh hasil $x^{2}$ hitung sebesar 4,912 yang kemudian dibandingkan dengan $x_{\text {tabel, }}^{2}$ yaitu 3,481 dengan kriteria pengujian sebagai berikut:Ha : $\quad$ Ada

Pengaruh Status Gizi (LILA) Remaja Terhadap Usia Menarche pada Siswi SDN Dukuh Menanggal Surabaya. ( Jika nilai $x_{\text {hitung }}^{2}>x_{\text {tabel, }}^{2}$ ) Dengan Taraf signifikan $=0,05 \mathrm{dan} d \mathrm{k}=1$

Berdasarkan kriteria pengujian hipotesis $x^{2}$ hitung lebih besar dari $x^{2}{ }_{\text {tabel }}(4,912>3,481)$ dengan demikian $\mathrm{Ha}$ diterima dan Ho ditolak sehingga dapat disimpulkan bahwa "Ada Pengaruh Status
Gizi Remaja Terhadap Usia Menarche pada Siswi SDN Dukuh Menanggal Surabaya" dapat diterima dan dibuktikan kebenarannya.

\section{Identifikasi Status Gizi Pada Siswi}

Data status gizi pada siswi SDN Dukuh Menanggal yang dijadikan responden pada Bulan Juni 2012 yang terbanyak status gizinya baik sebanyak 23 orang $(63,9 \%)$.

Hasil penelitian pada responden siswi SDN Dukuh Menanggal menujukkan bahwa responden sebagian besar dalam kategori gizi baik karena dari pengukuran lingkar lengan atas banyak yang menunjukkan diatas parameter yang ditentukan berdasarkan usia mereka, dan juga secara visual siswi berat badan mereka pas dengan tinggi badan yang proporsional.

\section{Identifikasi Usia Menarche Pada Siswi}

Data usia menarche pada siswi SDN Dukuh Menanggal yang dijadikan responden pada Bulan Juni 2012 yang terbanyak adalah menarche normal sebanyak 29 orang (80,6 \%). Hasil penelitian menunjukkan bahwa hampir seluruh siswa untuk usia menarche dalam kondisi normal, masa datangnya haid pada siswi semuanya terjadi pada usia diatas 10 tahun, hal ini terjadi hampir $80,5 \%$ dari seluruh responden. Percepatan proses menarche juga dipengaruhi oleh perubahan hormon steroid estrogen dan progesteron yang mempengaruhi pertumbuhan endometrium, semakin baik gizi siswi maka semakin cepat siswi akan mengalami menarche. Hal ini terbukti dengan adanya siwi di SDN Dukuh Menanggal yang mengalami menarche dini sebesar $19,4 \%$. Sehingga dari penelitian ini tidak ada siswi yang mengalami keterlambatan menarche semuanya berjalan pada usia yang normal.

\section{Hubungan Status Gizi Remaja Terhadap Usia Menarche pada Siswi SDN Dukuh Menanggal Surabaya}

Usia menarche dipengaruhi oleh status gizi, semakin gemuk seseorang pada usia-usia antara 10 tahun maka peluang mengalami menarche dini lebih besar, dan sebaliknya seseorang dengan tingkat status gizi yang 
normal. Sehingga memang sangat berpengaruh antara status gizi dengan usia menarche, Makasecaragaris besar berdasarkan analisis data menggunakan chi-square, $x^{2}$ hitung lebih besar dari $x^{2}$ tabel $(4,912>3,481)$ dengan demikian $\mathrm{Ha}$ diterima dan Ho ditolak sehingga dapat disimpulkan bahwa "Ada Pengaruh Status Gizi Remaja Terhadap Usia Menarche pada Siswi SDN Dukuh Menanggal Surabaya" dapat diterima dan dibuktikan kebenarannya. Hasil tabulasi silang antara status gizi dengan usia menarche pada siswi SDN Dukuh Menanggal bahwa yang mengalami gizi kurang semuanya pada usia menarche normal sebesar 13 orang $(36,1 \%)$ dan siswi yang mengalami gizi baik yang mengalami menarche dini sebanyak 7 orang $(19,4 \%)$ dan menarche normal sebanyak 16 orang $(44,4 \%)$.

\section{Simpulan dan Saran}

Simpulan dalam penelitian ini adalah :1)Status Gizi pada siswi SDN Dukuh Menanggal Surabaya terbanyak pada kategori gizi baik, 2) Usia Menarche pada siswi SDN Dukuh Menanggal Surabaya terbanyak pada kategori menarche normal,3)Ada Pengaruh Status Gizi Remaja Terhadap Usia Menarche pada Siswi SDN Dukuh Menanggal Surabaya.Berdasarkan kesimpulan tersebut, dapat disarankan sebagai berikut :1)Bagi Penulis, Memperluas pengamatan dengan memperbanyak kasus melalui penambahan sampel. 2)Bagi Siswi SDN Dukuh Menanggal,Diharapkan bagi siswi untuk aktif mencari informasi dan mengamati diri sendiri. 3)Bagi Orang tua,Memantau putrinya.

\section{DAFTAR ACUAN}

Arikunto. Suharsimi, 1998. Prosedur Penelitian. Jakarta : Rineka Cipta

Berg Alan. 1986. Gizi dan Pembangunan Nasional. Jakarta : Barata Karya Aksara

Burhanuddin. 2007. Tumbuh Kembang anak Dan Remaja. Jakarta : Sagung Seto.
Kartono Kartini. 2006. Psikologi Wanita. Bandung : Penerbit Buku Kedokteran EGC

Mochtar Rustam. 1998. Sinopsis Obstetri. Edisi 2. Jakarta : Penerbit Buku Kedokteran EGC

Notoatmodjo S. 2002. Pendidikan Perilaku Kesehatan. Jakarta : Rineka Cipta

Nursalam dan Pariani. 2003. Pendekatan Praktis Metodologi Riset Keperawata | Jakarta : EGC

Prayogo, Savitri. 2008. Menuju Perempuan Sehat dan Aktif melalui Gzi Seimbang. Jakarta : Fakultas Kedokteran Universitas Indonesia

Sarwono Prawiroharjo. 2007. Ilmu Kandungan. Jakarta : YPPS SP

Soetjiningsih, 2004. Tumbuh Kembang Anak. Jakarta : EGC

Suryabrata Sumadi, 1993. Metodologi Penelitian, Rineka Cipta, Jakarta

TIM Penyusun, 2012. Buku Panduan Penyusunan Usulan Proposal dan Karya Tulis Ilmiah, Surabaya, Program D-III Kebidanan Unipa Surabaya.

\section{Remaja dan Psikologis}

Menghadapinya. Seminar Nasional dan Lokakarya. FK. Universitas Sriwijaya. 


\title{
PENGETAHUAN IBU TENTANG DETEKSI DINI KANKER LEHER RAHIM DENGAN PAPSMEAR (Studi Kasus Di BPS Lilik Farida Surabaya)
}

\author{
Erlinda Aisa ${ }^{1}$, Sumiati ${ }^{2}$ \\ 1. Mahasiswa Program Studi D III Kebidanan Universitas PGRI Adi Buana Surabaya \\ 2. Tenaga Pengajar Program Stdi D III Kebidanan Universitas PGRI Adi Buana Surabaya
}

\begin{abstract}
ABSTRAK
Deteksi dini kanker leher rahim di Indonesia masih jarang ditemui, hal ini disebabkan oleh ketidaktahuan masyarakat tentang pentingnya deteksi dini kanker leher rahim, khususnya pada wanita usia reproduksi yang dapat dipengaruhi oleh beberapa faktor dan karakteristik ibu. Di Indonesia angka kematian ibu yang terjangkit kanker leher rahim masih sangat tinggi yang disebabkan oleh banyak hal salah satunya adalah bahan makanan yang banyak mengandung zat kimia. Tujuannya mengidentifikasi pengetahuan ibu tentang deteksi dini kanker leher rahim dengan papsmear berdasarkan usia, pendidikan, dan pekerjaan.

Desain penelitian menggunakan metode statistik deskriptif persentasi. Jumlah sampelnya ditetapkan sebanyak 30 responden akseptor KB pengambilan sampel dilakukan dengan menggunakan total sampling. Data diambil dengan menggunakan kuisioner, setelah data terkumpul diteliti kembali apakah data sudah cukup baik dan dapat disiapkan untuk proses berikutnya.

Hasil penelitian diperoleh 30 responden secara umum memiliki pengetahuan baik 11 responden (37\%), yang berpengetahuan cukup 13 responden (43\%), yang berpengetahuan kurang 6 responden (20\%). Berdasarkan usia responden yang berusia $20-30$ thn didapatkan pengetahuan baik 11 responden (40\%), pengetahuan cukup 11 responden (40\%) dan pengetahuan kurang 3 responden $(12 \%)$. Berdasarkan pendidikan didapatkan hasil : pengetahuan baik 4 responden $(37 \%)$ dengan pendidikan Perguruan Tinggi, pengetahuan cukup 7 responden (54\%) dengan pendidikan SLTA dan sebanyak 6 responden (100\%) dengan pendidikan SD - SLTP. Berdasarkan pekerjaan didapatkan hasil : responden pekerja swasta memiliki pengetahuan cukup 10 responden (59\%), PNS terbanyak pengetahuan cukup 2 responden (100\%) dan tidak bekerja terbanyak 7 responden (67\%) pengetahuan cukup. Adapun saran yang disampaikan, peneliti berharap dapat mengubah pola pikir masyarakat yang mengenyampingkan pemeriksaan papsmear dan tenaga kesehatan dapat meningkatkan upaya promotif menggalakkan penyuluhan khususnya untuk kesehatan reproduksi wanita diberbagai wilayah tidak hanya kota saja tetapi juga daerah yang sulit dijangkau.
\end{abstract}

Kata kunci : Pengetahuan ibu, deteksi kanker leher rahim, papsmear

\section{PENDAHULUAN}

\section{Latar Belakang}

Sebagai seorang wanita kita perlu menjaga kondisi tubuh mulai dari ujung rambut sampai kaki, tidak hanya bagian luar saja yang dirawat dan dijaga melainkan organ dalam pun juga harus diperhatikan, misalnya rahim banyak mengalami perubahan yang tidak menentu hal ini harus diwaspadai pada setiap orang, perlunya pemeriksaan papsmear ditujukan untuk menurunkan angka kematian akibat kanker leher rahim. Dengan papsmear kanker leher rahim bisa terdeteksi lebih awal dan dapat disembuhkan jika stadium awal. Saat ini banyak ditemui wanita datang berobat setelah timbul suatu gejala seperti keputihan yang banyak dan berbau menyengat ternyata setelah diperiksa ditemukan sudah stadium lanjut. Penting dalam papsmear adalah pemeriksaan vagina dengan spekulum untuk diambil sampel cairan porsionya dan diperiksakan ke laboratorium.

Total jumlah wanita yang didiagnosis kanker leher rahim di Amerika Serikat pada tahun 1999 adalah 12900 dengan kematian yang berkaitan dengan kanker sejumlah 4400, sedangkan wanita yang mengidap kanker leher rahim di seluruh dunia sekitar 471000, dengan angka kematian 215000. Di banyak negara berkembang, kanker leher rahim merupakan penyebab kematian paling umum di usia reproduksi.(Rasjidi, Imam.2009;99)

Diagnosis kanker leher rahim masih
sering terlambat 
penanganannyapun ternyata tidak memberi hasil yang baik. Terlambatnya diagnosis terjadi karena penderita sering datang terlambat ke dokter ataupun disebabkan gejala yang sulit terdeteksi oleh dokter menemukan penyakit tersebut pada tingkat dini.

Biasanya penderita datang ke dokter setelah terjadi gejala perdarahan per vaginam yang tidak semestinya atau terdapat keputihan yang berbau. Jika terjadi perdarahan per vagina atau terdapat keputihan, sering wanita tidak pergi ke dokter tetapi mengusahakan sendiri mengatasinya dengan minum jamu atau pergi ke dukun. Apabila dengan usaha tersebut gejala tidak teratasi atau mungkin menghebat, barulah mereka pergi ke dokter. Hal ini disebabkan karena kurangnya pengertian akan bahaya kanker, karena pendidikan yang kurang atau kurangnya penerangan mengenai kanker umumnya, kanker leher rahim khususnya. Tidak jarang pula mereka takut jika dokter menemukan kanker pada dirinya. Ketakutan yang tidak beralasan ini dikarenakan bahwa kanker tidak dapat diobati dan selalu dihubungkan dengan kematian.

Dilakukannya deteksi dini dengan papsmear untuk mengetahui ada tidaknya penyakit kanker leher rahim, jika seorang wanita terjangkit maka segera dilakukan pemeriksaan lebih lanjut dengan berbagai terapi jika stadium awal besar kemungkinan bisa disembuhkan namun jika stadium sudah lanjut bisa dilakukan kemoterapi, kalau di biarkan atau tidak terdeteksi saat ini maka akan berakhir dengan kematian.

Tujuan Umum dalam penelitian ini adalah: mengetahui pengetahuan ibu tentang deteksi dini kanker leher rahim dengan papsmear. Tujuan khususnya adalah : 1. Mengidentifikasi pengetahuan ibu tentang deteksi dini kanker leher Rahim dengan papsmear secara umum, 2. Mengidentifikasi pengetahuan ibu tentang deteksi dini kanker leher Rahim dengan papsmear berdasarkan usia, 3. Mengidentifikasi pengetahuan ibu tentang deteksi dini kanker leher Rahim dengan papsmear berdasarkan pendidikan, 4. Mengidentifikasi pengetahuan ibu tentang deteksi dini kanker leher Rahim dengan papsmear berdasarkan pekerjaan.

\section{Bahan dan Metode}

Rancangan penelitian yang dipilih adalah penelitian diskriptif, dimana peneliti berupaya menggambarkan pengetahuan tentang deteksi dini kanker leher Rahim dengan papsmear. Penelitian dilakukan di BPS Lilik Farida yang dilaksanakan pada bulan Juni 2012. Populasi dalam penelitian adalah semua Akseptor KB sebanyak 30 responden. Pengambilan sample dengan total sampling dan instrument penelitian menggunakan angket / kuisioner untuk mengukur pengetahuan ibu. Data yang dikumpulkan oleh peneliti berupa data karakteristik ibu ( umur, pendidikan, pekerjaan ) dan pengetahuan ibu tentang deteksi dini kanker leher rahim dengan papsmear. Setelah data terkumpul selanjutnya di analisis dengan statistik, diskriptif persentase.

\section{Hasil dan pembahasan}

Berdasarkan penelitian terhadap 30 responden didapatkan hasil sebagai berikut :

Tabel 1. Distribusi Frekuensi Responden Berdasarkan Pengetahuan lbu Tentang Deteksi Dini Dengan Papsmear Di BPS Lilik Farida Surabaya Pada Bulan Juni 2012

\begin{tabular}{|c|c|c|c|}
\hline No & Pengetahuan & $\mathrm{n}$ & $\%$ \\
\hline 1 & Baik & 11 & $37 \%$ \\
2 & Cukup & 13 & $43 \%$ \\
3 & Kurang & 6 & $20 \%$ \\
\hline & Jumlah & 30 & $100 \%$ \\
\hline
\end{tabular}

Berdasarkan tabel 1 dapat dijelaskan bahwa dari 30 responden yang berpengetahuan baik 11 responden $(37 \%)$, yang berpengetahuan cukup 13 responden (43\%), yang berpengetahuan kurang 6 responden (20\%).

Tabel 2. Tabulasi Silang Pengetahuan Ibu Tentang Deteksi Dini Dengan Papsmear Berdasarkan Usia Di BPS Lilik Farida Surabaya.

\begin{tabular}{|c|l|c|c|c|c|c|c|c|c|}
\hline \multirow{3}{*}{ No } & \multirow{3}{*}{$\begin{array}{l}\text { Penget } \\
\text { ahuan }\end{array}$} & \multicolumn{4}{|c|}{ Usia (tahun) } & \multicolumn{2}{|c|}{$\Sigma$} \\
\cline { 3 - 10 } & & $<20$ & $20-30$ & \multicolumn{2}{|c|}{$\Sigma$} \\
\cline { 3 - 10 } & $\mathrm{n}$ & $\%$ & $\mathrm{n}$ & $\%$ & $\mathrm{n}$ & $\%$ & $\mathrm{n}$ & $\%$ \\
\hline 1 & Baik & 0 & 0 & 11 & 40 & 0 & 0 & 11 & 100 \\
2 & Cukup & 0 & 0 & 11 & 40 & 2 & 15 & 13 & 100 \\
3 & Kurang & 0 & 0 & 3 & 12 & 3 & 50 & 6 & 100 \\
\hline
\end{tabular}

Dari tabel diatas dapat disimpulkan bahwa dari 30 responden, 20-30 tahun yang mempunyai pengetahuan baik dalam pemeriksaan papsmear 
terbanyak 11 responden (100\%), 20-30 tahun yang mempunyai pengetahuan cukup terbanyak 11 responden (85\%), dan > 40 tahun yang mempunyai pengetahuan kurang terbanyak 3 responden $(50 \%)$.

Tabel 3. Tabulasi Silang Pengetahuan lbu Tentang Deteksi Dini Dengan Papsmear Berdasarkan Pendidikan Di BPS Lilik Farida Surabaya

\begin{tabular}{|c|l|c|c|c|c|c|c|c|c|}
\hline \multirow{2}{*}{ No } & \multirow{2}{*}{$\begin{array}{l}\text { Penget } \\
\text { ahuan }\end{array}$} & \multicolumn{5}{|c|}{ Pendidikan } & \multicolumn{2}{|c|}{$\begin{array}{c}\text { SD- } \\
\text { ahu }\end{array}$} & \multicolumn{2}{|c|}{ SLTA } & \multicolumn{2}{|c|}{ PT } & \multicolumn{2}{|c|}{$\Sigma$} \\
\cline { 3 - 10 } & & $\mathrm{n}$ & $\%$ & $\mathrm{n}$ & $\%$ & $\mathrm{n}$ & $\%$ & $\mathrm{n}$ & $\%$ \\
\hline 1 & Baik & 4 & 37 & 3 & 27 & 4 & 37 & 11 & 100 \\
2 & Cukup & 6 & 46 & 7 & 54 & 0 & 0 & 13 & 100 \\
3 & Kurang & 6 & 100 & 0 & 0 & 0 & 0 & 6 & 100 \\
\hline
\end{tabular}

Dari tabel diatas dapat disimpulkan bahwa 30 responden yang berpendidikan SD-SLTP dan PT yang mempunyai pengetahuan baik terbanyak 4 responden (37\%), yang berpendidikan SLTA mempunyai pengetahuan cukup terbanyak 7 responden (54\%), yang berpendidikan SD-SLTP mempunyai pengetahuan kurang terbanyak 6 responden (100\%).

Tabel 4. Tabulasi Silang Pengetahuan lbu Tentang Deteksi Dini Dengan Papsmear Berdasarkan Pekerjaan Di BPS Lilik Farida Surabaya.

\begin{tabular}{|c|l|c|c|c|c|c|c|c|c|}
\hline \multirow{2}{*}{ No } & \multirow{2}{*}{$\begin{array}{c}\text { Penget } \\
\text { ahuan }\end{array}$} & \multicolumn{6}{|c|}{$\begin{array}{c}\text { Pengetahuan tentang } \\
\text { Papsmear }\end{array}$} & $\begin{array}{c}\text { Tidak } \\
\text { bekerja }\end{array}$ & \multicolumn{2}{|c|}{ Swasta } & \multicolumn{2}{c|}{ PNS } & \multicolumn{3}{c|}{$\Sigma$} \\
\cline { 3 - 10 } & & $\mathrm{n}$ & $\%$ & $\mathrm{n}$ & $\%$ & $\mathrm{n}$ & $\%$ & $\mathrm{n}$ & $\%$ \\
\hline 1 & Baik & 3 & 27 & 7 & 41 & 2 & 100 & 12 & 100 \\
2 & Cukup & 7 & 67 & 10 & 59 & 0 & 0 & 17 & 100 \\
3 & Kurang & 1 & 6 & 0 & 0 & 0 & 0 & 1 & 100 \\
\hline
\end{tabular}

Dari tabel diatas dapat disimpulkan bahwa dari 30 responden yang swasta mempunyai pengetahuan baik terbanyak 7 responden $(41 \%)$, yang swasta mempunyai pengetahuan cukup terbanyak 10 responden (59\%), yang tidak bekerja mempunyai pengetahuan kurang terbanyak 1 responden (6\%).

\section{PEMBAHASAN}

Setelah dianalaisa dan dijabarkan dalam bentuk tabel akan diuraikan tentang pembahasan hasil penelitian yang telah dilakukan dari data diatas sehingga dapat disimpulkan bahwa pengetahuan ibu tentang deteksi dini kanker leher rahim dengan papsmear dapat di pengaruhi oleh usia, pendidikan, dan pekerjaan.

\section{Pengetahuan Ibu Tentang Deteksi Dini Kanker Leher Rahim Dengan Papsmear Secara Umum}

Berdasarkan hasil penelitian pengetahuan tentang deteksi dini kanker leher rahim dengan papsmear sesuai dengan tabel 1 maka dapat diperoleh bahwa dari 30 responden yang berpengetahuan baik 11 responden (37\%), yang berpengetahuan cukup 13 responden $(43 \%)$, yang berpengetahuan kurang 6 responden $(20 \%)$.

\section{Pengetahuan Ibu Tentang Deteksi Dini Kanker Leher Rahim Dengan Papsmeaar Berdasarkan Usia}

Usia adalah umur individu yang terhitung mulai saat dilahirkan sampai saat berulang tahun. Semakin cukup umur tingkat kematangan dan kekuatan seseorang akan lebih matang dalam berpikir, bersosialisasi, dan beraktifitas dalam kehidupan sehari-hari. Dari kepercayaan masyarakat yang lebih dewasa akan lebih dipercaya dari pada orang yang belum cukup tinggi kedewasaannya. Hal ini sebagai akibat dari pengalaman dan kematangan jiwanya (Nursalam,2003)

Hal ini tidak sesuai dengan teori berdasarkan tabel 2 ditemukan bahwa dari 30 responden 20-30 tahun yang mempunyai pengetahuan baik dalam pemeriksaan papsmear terbanyak 11 responden (100\%), 20-30 tahun yang mempunyai pengetahuan cukup terbanyak 11 responden (85\%), dan > 40 tahun yang mempunyai pengetahuan kurang terbanyak 3 responden $(50 \%)$, hal ini dikarenakan pada usia 20-30 tahun adalah usia produktif sehingga pola pikir/ pengetahuan tentang papsmear masih sangat tinggi sedangkan pada usia $>40$ tahun beranggapan bahwa melakukan pemeriksaan itu tidak penting lagi kemungkinan besar dikarenakan usia mereka yang mendekati masa menopause serta enggan untuk diperiksa karena harus membuka anggota tubuh bagian bawah.

\section{Pengetahuan Ibu Tentang Deteksi Dini Kanker Leher Rahim Dengan Papsmeaar Berdasarkan Pendidikan}


Berdasarkan tabel 3 dapat dilihat bahwa dari 30 responden berpendidikan SD-SLTP dan PT yang mempunyai pengetahuan baik terbanyak 4 responden (37\%), yang berpendidikan SLTA mempunyai pengetahuan cukup terbanyak 7 responden (54\%), yang berpendidikan SD-SLTP mempunyai pengetahuan kurang terbanyak 6 responden (100\%). Menurut Notoadmodjo (2007) makin tinggi tingkat pendidikan seseorang makin mudah menerima informasi sehingga makin banyak pula pengetahuan yang diperkenalkan.

Dalam penelitian ini tidak ditemukan kesesuaian teori yang menyatakan bahwa tingkat pendidikan menentukan pengetahuan. $\mathrm{Hal}$ ini dapat terjadi karena keinginan dari dalam diri mereka untuk mencari informasi terbaru misalnya melalui media masa, internet, dan pengetahuan yang didapat dari pendidikan kesehatan demi kesehatan tubuh mereka masing-masing, sehingga mampu menentukan sikap untuk mengambil keputusan dalam melakukan pemeriksaan dengan rutin.

\section{Pengetahuan Ibu Tentang Deteksi Dini Kanker Leher Rahim Dengan Papsmeaar Berdasarkan Pekerjaan}

Berdasarkan tabel 4 dapat dilihat bahwa sebagian besar responden tidak bekerja yaitu sebanyak 15 responden (50\%). Menurut Nursalam (2003) seseorang yang mempunyai pekerjaan penting dan memerlukan aktifitas, maka akan merasa tidak ada waktu untuk memeriksakan kesehatan diri masing-masing, tapi tidak semua orang yang bekerja seperti demikian sebagian dari mereka dapat melakukan pemeriksaan dengan baik

Dalam penelitian ini berdasarkan tabel 4 ditemukan tidak sesuai dengan teori menurut Nursalam (2003) dari 30 responden yang bekerja swasta mempunyai pengetahuan baik terbanyak 7 responden (63\%), yang bekerja swasta mempunyai pengetahuan cukup terbanyak 8 responden (62\%), yang tidak bekerja mempunyai pengetahuan kurang terbanyak 1 responden (100\%), ibu yang bekerja swasta maupun PNS mempunyai pengetahuan baik karena kawatir akan kondisinya, meskipun mereka bekerja dan mempunyai waktu terbatas tapi mereka dapat meluangkan waktu untuk periksa papsmear dengan harapan jika terdapat gejala dapat diketahui sejak dini untuk kesehatan jangka panjang.

\section{SIMPULAN DAN SARAN}

\section{Simpulan}

Jadi dari hasil penelitian yang telah dilakukan didapatkan pembahasan seperti diatas sehingga dapat disimpulkan bahwa dari pengetahuan ibu untuk deteksi dini kanker leher rahim dengan papsmear berdasarkan usia, pendidikan, dan pekerjaan didapatkan dari 30 responden yang diamati hampir sebagian besar mempunyai pengetahuan baik dan pembahasan mengenai pengetahuan ibu untuk deteksi dini kanker leher rahim dengan papsmear di BPS Lilik Farida Surabaya dapat dibuktikan bahwa:

1. Pengetahuan ibu tentang deteksi dini kanker leher rahim dengan papsmear secara umum yang diperoleh dari 30 responden yang berpengetahuan baik 11 responden (37\%), yang berpengetahuan cukup 13 responden (43\%), yang berpengetahuan kurang 6 responden (20\%).

2. Pengetahuan ibu tentang deteksi dini kanker leher rahim dengan papsmear berdasarkan usia, 20-30 tahun yang mempunyai pengetahuan baik dalam pemeriksaan papsmear terbanyak 11 responden (40\%), yang mempunyai pengetahuan cukup 11 responden (40\%), dan pada usia $>40$ tahun yang mempunyai pengetahuan kurang terbanyak 3 responden (12\%).

3. Berdasrkan pendidikan didapatkan hasil : pengetahuan baik 4 responden (37 \%) dengan pendidikan perguruan tinggi, pendidikan cukup 7 responden (54\%) dengan pendidikan SLTA dan sebanyak 6 responden (100\%) dengan pendidikan SD SLTP.

4. Berdasarkan pekerjaan didapatkan hasil : responden pekerja swasta memiliki pengetahuan cukup 10 responden (59\%), PNS terbanyak pengetahuan cukup 2 responden $(100 \%)$ dan tidak bekerja terbanyak 7 responden (67\%) pengetahuan cukup.

\section{Saran}

\section{Bagi Pelayanan Kesehatan}

Petugas dipelayanan kesehatan diharapkan memberikan pendidikan kesehatan, pentingnya pengetahuan tentang deteksi dini kanker leher rahim dengan papsmear kepada akseptor KB. 


\section{Bagi Akseptor KB}

Dalam upaya meningkatkan pengetahuan tentang deteksi dini kanker leher rahim dengan papsmear, perlu mengikuti penyuluhan-penyuluhan dari tenaga kesehatan, bisa juga melalui media masa.

\section{Peneliti Selanjutnya}

Perlu diadakan penelitian lebih lanjut tentang perilaku akseptor KB dalam melakukan pemeriksaan papsmear terhadap dirinya.

\section{DAFTAR ACUAN}

Arifin, Zainal. 2010. Metodelogi Penelitian. Surabaya:Lentera Cendikia

Ghofar, Abdul. 2009. Cara Mudah Mengenal \& Mengobati Kanker. Yogyakarta:Flamingo

Hidayat, A.Aziz Alimul.2007.Metode Penelitian Kebidanan Teknisi Analisa Data.Jakarta:Salemba Medika

Mangan, Yelia.2005.Cara Bijak Menaklukkan Kanker.Jakarta:Agro Media Pustaka

Manuaba, Ida Bagus Gde.1998.IImu Kebidanan, Penyakit Kandungan dan Keluarga Berencana untuk Pendidikan Bidan.Jakarta:EGC

Margatan,Arcole.1996. Waspada Kanker Payudara\&Rahim.Solo:CV.Aneka

Norwitz,Errol.2007.At a Glance Obstetri\&Ginekologi.Jakarta:Airlangga

Notoatmodjo,Soekidjo.2007.Metodologi Penelitian Kesehatan.Jakarta:Rineka Cipta

Nurcahyo,Jalu.2010.Awas Bahaya Kanker Rahim dan Kanker Payudara. Yogyakarta:Wahana Totalita.

Nursalam.2001.Manajemen Keperawatan.Jakarta:Salemba Medika

Prawirahardjo,Sarwono.2009. IlmuKebidanan.

\section{Jakarta:YBPSP}

Rahayu, Wahyu.2011.Mengenali,Mencegah Dan Mengobati 35 Jenis Kanker.: Victory Inti Cipta

Rasjidi, Imam.2009.Deteksi Dini \& Pencegahan Kanker Pada Wanita.Jakarta:CV Sagung Seto

Rasjidi,Imam.2010.EpidemiologiKanker. Jakarta:CV Sagung Seto

Rustam,Harahap.1984.Neoplasia Intraepitel pada Servik.Jakarta:Universitas Indonesia 